This is a non-peer reviewed preprint submitted to EarthArXiv. It has been submitted for publication in Quaternary Geochronology and has yet to be accepted for publication. Subsequent versions of this manuscript may have slightly different content. If accepted, the final published version of this manuscript will be available via the "Peer-reviewed Publication DOI" link. Please contact the corresponding author with any feedback.

\title{
Accurate chronological construction for two young stalagmites from the
}

\section{tropical South Pacific}

Mohammadali Faraji, ${ }^{a}$, Silvia Frisiaa, Quan Hua ${ }^{b}$, Andrea Borsato ${ }^{a}$, Monika Markowska ${ }^{c}$

a. School of Environmental and Life Sciences, The University of Newcastle, NSW 2308, Australia.

b. Australian Nuclear Science and Technology Organisation, Locked Bag 2001, Kirrawee DC, NSW 2232, Australia.

c. Climate Geochemistry Department, Max Planck Institute for Chemistry, 55128 Mainz, Germany.

*Correspondence to: M.F. (mohammadali.faraji@uon.edu.au)

\section{Abstract}

Modern to Holocene tropical Pacific stalagmites are commonly difficult to date with the U-series, the most commonly used dating method for speleothems. When U-series does not provide robust age models, due to multiple sources of ${ }^{230}$ Th or little $U$, radiocarbon is, potentially, the best alternative. The ${ }^{14} \mathrm{C}$ content of two stalagmites (Pu17 and Nu16) collected from Pouatea and Nurau caves in the Cook Island Archipelago of the South Pacific were measured to obtain accurate chronology for their most modern parts. The bomb-pulse soil continuum modelling indicates that bomb radiocarbon in Pu17 onsets in 1956 and reaches its maximum in 1966 CE, suggesting a fast transfer of atmospheric carbon to the stalagmite of $<1$ year. The modelling for Pu17 suggests a $20 \%$ contribution from $C_{1}$ - an instantaneous carbon source, which renders possible an immediate transfer of atmospheric signal into the cave. Nu16 shows a slower transfer of atmospheric carbon to the stalagmite than Pu17, with bomb radiocarbon onsetting in $1957 \mathrm{CE}$ and peaking in $1972 \mathrm{CE}$. The less negative $\delta^{13} \mathrm{C}$ values in Nu16 than 
Pu17, and also the modelling corroborated this, which points out no contribution from the instantaneous carbon source. The radiocarbon age models and laminae counting age models were then spliced to achieve a single master chronology for the top part of each stalagmite. This study is an example of ${ }^{14} \mathrm{C}$ age modelling combined with visible physical and chemical laminae counting and how speleothems. Such accurate and precise age models pave the way to obtain sub-annually resolved paleoclimate records by further improving the calibration of climate proxy data with the current and instrumental weather parameters.

34 Keywords: radiocarbon, chronological construction, Southern Cook Islands, speleothems, tropical 35 South Pacific. 


\section{Introduction}

In the last couple of decades, speleothems have been used to develop terrestrial paleoclimate reconstructions on a wide range of temporal resolutions from seasonal to millennial scales (Fairchild and Baker, 2012). These records are now available for different climate settings (e.g. Bar-Matthews et al., 1999; Li et al., 2005; Vansteenberge et al., 2020; Wang et al., 2019), but scarce for the South Pacific islands. Additionally, the instrumental records in this region are typically short and incomplete, providing only a snap-shot of the range of regional natural climate variability. The South Pacific islanders are highly vulnerable to the effects of both climate variability (Cai et al., 2015) and climate

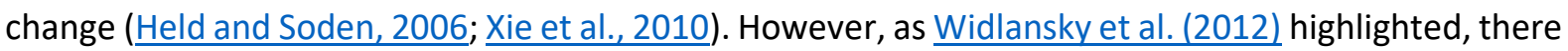
is significant uncertainty in how the South Pacific Convergence Zone (SPCZ), the largest rainband in the Southern Hemisphere, will respond in the future under a changing climate. Therefore, there is sufficient justification for developing robust, accurately dated paleoclimate reconstructions from stalagmites, given that in this region, water for agriculture is almost entirely supplied by rainfall rather than by irrigation systems (Barnett, 2011).

One of the strengths of speleothems as a paleoclimatic archive is, arguably, their capability to be

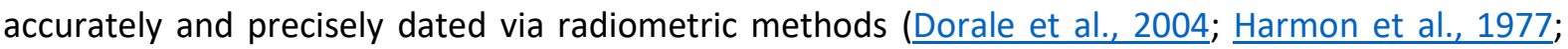
Hellstrom, 2006; Richards et al., 1998; Scholz and Hoffmann, 2008; Zhao et al., 2003). The U-series disequilibrium method is the most commonly used dating method for speleothems ( In the case that $\mathrm{U}$-series dating cannot be applied, for example, because of multiple sources of ${ }^{230} \mathrm{Th}$ (Hua et al., 2012), robust relative chronologies can be acquired via counting annual visible chemical and physical laminae (Baker et al., 2021) on two-dimensional maps (Faraji et al., 2021; Oriani et al., 2022). This approach may also entail considerable uncertainties, particularly in the youngest, modern parts of the speleothem due to fabric complexity maps (Faraji et al., 2021). An alternative method for obtaining accurate age models and further constraining the age of modern speleothems(1950 CE present) is using the radiocarbon $\left[{ }^{14} \mathrm{C}\right]$ "bomb-pulse" method (e.g. Genty and Massault, 1999; $\underline{\text { Hodge }}$ 
Scroxton et al., 2021). Calibrated radiocarbon ages can also be used as an age constraint up to 50 ka.

63

However, its use in speleothems is complicated by the contribution of 'radioactively dead' carbon, known as Dead Carbon Proportion (DCP), derived from ${ }^{14} \mathrm{C}$-depleted material from bedrock and aged soil organic matter. Consequently, when comparing the radiocarbon ages of speleothems to the ages obtained by the U-Th method, they commonly show older ages (Beck et al., 2001; Goslar et al., 2000). A thorough understanding of DCP variations in a speleothem then can pave the way to generate a reliable radiocarbon chronology and also gain insight into the variability of water-rock interactions through time (Bajo et al., 2017; Griffiths et al., 2012).

We studied two stalagmites (Pu17 from Pouatea cave and Nu16 from Nurau cave) retrieved from Atiu Island, in the South Pacific to obtain accurate and precise chronologies, which is fundamental for robust paleoclimate reconstructions. Similar to other speleothems from Pacific Island caves, which are cut in reef limestone, speleothems in Atiu are expected to provide an excellent opportunity for radiocarbon dating. That is because the rock burden above caves is 2 to $8 \mathrm{~m}$, characterized by high porosity resulting from incomplete diagenesis of a relatively young reef. This shallow cave system, coupled with a limited and patchy soil cover, ensures rapid surface climate conditions transmission into the cave. Except for some small pockets of red clay soil filling the bottom of joint-controlled karst of colluvial origin (Stoddart et al., 1990), the surface above the cave is bare karst. Rapid transmission of rain signal into the cave reduces the interaction between rainwater and bedrock, thus, minimizing the contribution of bedrock-derived dead carbon, which is crucial for constructing reliable radiocarbon age-depth models.

In this study, we develop a chronology for modern portions of the two stalagmites from Atiu Island by using ${ }^{14} \mathrm{C}$ and the bomb pulse soil continuum method from Markowska et al. (2019). We then compare different chronologies available for Pu17 and Nu16, including laminae counting and radiocarbon age models, and discuss how they are combined to obtain accurate and precise chronologies, which pave 
the way towards reconstructing hydroclimate variability from speleothems that are difficult to date in their modern parts.

\section{Sample and site description}

The stalagmites selected for this study were retrieved from Atiu Island (7.25 km N-S and $6.3 \mathrm{~km} \mathrm{E-W),}$ the third-largest island in the Southern Cook Islands, located in latitude $20^{\circ} \mathrm{S}$ and longitude $158^{\circ} 10^{\prime} \mathrm{W}$ in the South Pacific (Fig. 1a, b). Atiu, as described by Stoddart et al. (1990), is a highly eroded volcanic island surrounded by a rim of elevated Cenozoic reefal limestone (i.e., the makatea - the Polynesian word for "white stone" referring to the reef limestone (Kirch, 2000)). The volcanic plateau of Atiu reaches a maximum height of $\approx 72 \mathrm{~m}$ above sea level (asl), mainly covered with limonitic-nodulebearing red clay. Based on foraminifera fossils, a Plio-Pleistocene age was attributed to the uplifted reefal limestone that once rimmed the volcanic island (Marshall, 1930).

The vegetation above both Nurau and Pouatea caves is thick, and soil cover is limited to patchy areas where it has concentrated in dissolution pits and trenches. Alfisols, Mollisols and Inceptisols are the main types of soils covering the island (Bruce, 1983). However, most of the karstified makatea is barren limestone, where tree roots find their way underground through dissolution cracks and voids in the absence of soil. The indigenous forest association above the caves consists of native Elaeocarpus tonganus and Hernandia moerenhoutiana. Alien species, typically coconut palms, mark human impact (Holland and Olson, 1989). Although a large number of weedy plants have become naturalized in the central volcanic interiors of Atiu, alien species have generally not been able to spread into the makatea.

\subsection{Pouatea cave and stalagmite Pu17}

Stalagmite Pu17 (Fig. 2) was actively growing when removed in March 2019 at a depth of ca. 7 m beneath the surface within a gallery leading to the cave's southern dead-end (Faraji et al., 2021). Pu17 was fed by a relatively slow and constant drip (1 drop every 15 minutes), which resulted in its candle- 

were actively growing, evidenced by the analysis of several dripwater in the cave indicating a $\mathrm{pH}$ of $\approx 8$ and the measured dripwater Saturation Index for calcite (SIcc) between 0.9 to 1 . Additionally, we observed calcite forming in situ on watch glasses placed under both relatively fast ( 1 drop per 11 seconds) and slow (1 drop per 50 seconds) drips. Stalagmite Pu17 is $53 \mathrm{~mm}$ long and grew over a stalagmite stump, likely broken by humans, which highlights the importance of speleothems as a ceremonial building material, according to Atiuan lore (Trotter and Duff, 1974). The stalagmite provides an opportunity to unravel the history of Polynesian land use as well as climate variability. network with several intersecting passages and side galleries with a total surveyed length of $1200 \mathrm{~m}$. The cave's main entrance is a vertical shaft with a drop of about $4 \mathrm{~m}$ that opens $23 \mathrm{~m}$ asl at $525 \mathrm{~m}$ from the shoreline. There are five other entrances (skylights) with diameters ranging from 3 to $10 \mathrm{~m}$ formed due to cave roof collapse. The rock overburden is 4 to $8 \mathrm{~m}$ thick, characterized by high porosity, likely due to a relatively young reef's incomplete diagenesis. The porous epikarst ensures rapid transmission of water through the vadose zone, further accelerated by the thin and patchy soil cover.

\subsection{Nurau cave and stalagmite Nu16}

Stalagmite Nu16 (Fig. 2) was retrieved from Nurau Cave in October 2018 at a depth of ca. $8 \mathrm{~m}$ beneath the surface from a dead-end chamber. Nu16 is a $100 \mathrm{~mm}$ long candle-shaped stalagmite. It was actively growing over a flowstone at the time of removal and was fed by a honey-coloured soda-straw stalactite. The drip rate varied from 1 drop/318 seconds in the relatively dry season (measured in October 2018) to 1 drop/48 seconds in the wet season (measured in March 2019). Nu16 shows clear laminae.

Nurau cave $\left(19^{\circ} 59^{\prime} 37^{\prime \prime} \mathrm{S}, 158^{\circ} 05^{\prime} 18^{\prime \prime} \mathrm{W}\right)$ is located on the eastern side of Atiu island. The cave entrance, which is a narrow passage at the bottom of a skylight, is $250 \mathrm{~m}$ from the shoreline and ca. $19 \mathrm{~m}$ asl. 
by evidence of old palaeokarst in the form of dissolution cavities filled by calcite cement crusts.
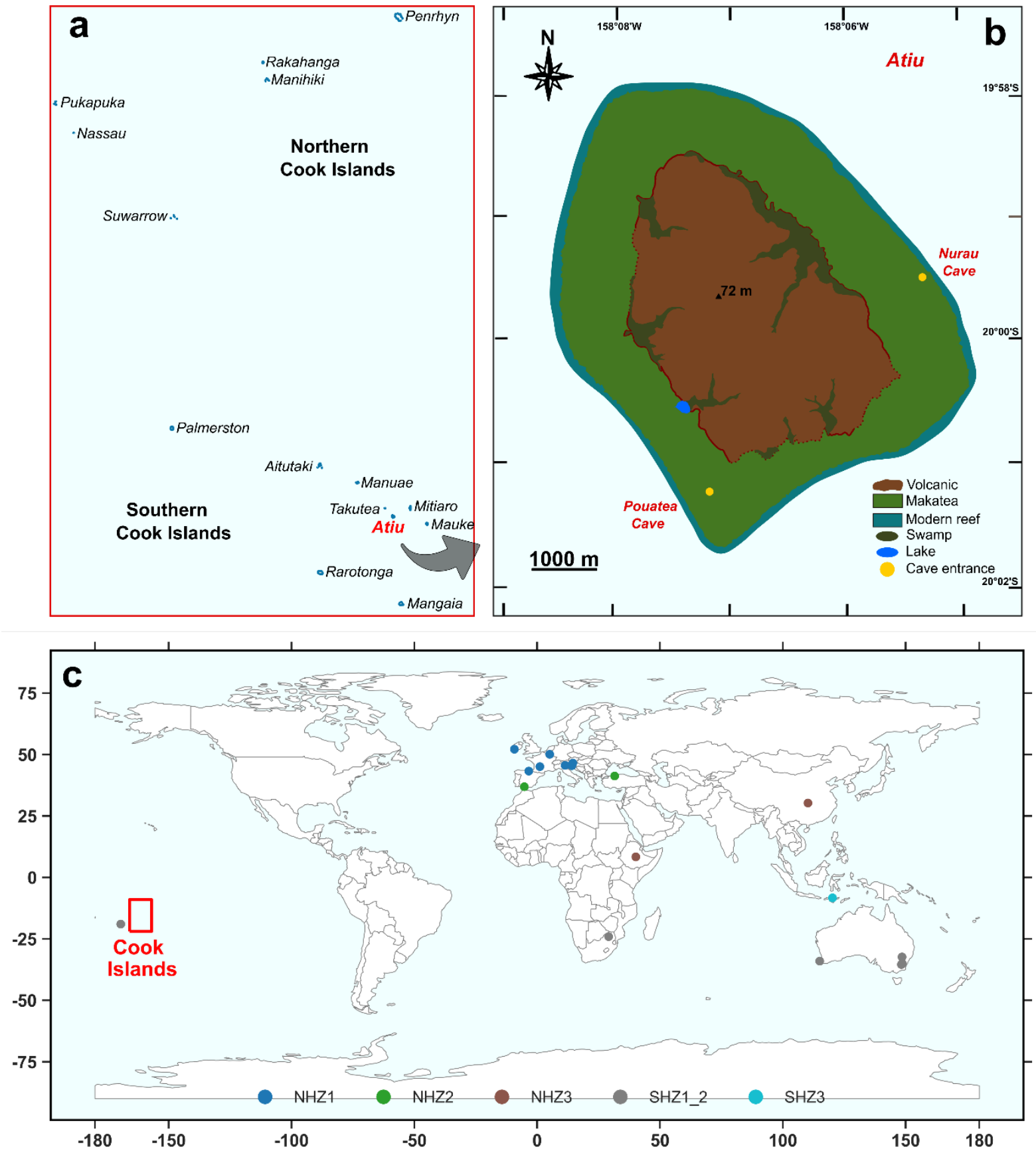

Fig. 1. $a$, the Northern and Southern groups of the Cook Islands (redrawn from Australian Bureau of Meteorology and CSIRO (2011)). b. Geomorphological map of Atiu Island (redrawn from Stoddart et al. (1990)) with the location of Pouatea and Nurau caves. c, location of Cook Islands and the bomb-pulse radiocarbon chronologies in the literature that was referred to in this study, the majority of which are from Northern Hemisphere Zone 1 (NHZ1). The stalagmite radiocarbon chronologies plotted in " $c$ " are grouped according to the atmospheric ${ }^{14} \mathrm{C}$ zones defined in Hua et al. (2021). 
145

146

147

\section{Methods}

Prior to constructing radiocarbon chronologies for Pu17 and Nu16, other techniques such as U-Th dating coupled with counting visible physical and chemical laminae were applied that led to reasonably accurate age models. This was then followed by radiocarbon measurements and building

${ }^{14} \mathrm{C}$ age models using the soil carbon continuum modelling (Markowska et al., 2019) that enhanced the accuracy of initial laminae and U-Th models. The final chronology for each stalagmite was constructed by splicing the laminae counting and radiocarbon age models.

\subsection{Laminae counting chronology}

Using high-frequency variations in visible growth laminae properties (Baker et al., 2015; Tan et al., 2006) or the cyclicity of their geochemical properties, such as trace element concentration (Ban et al., 2018; Borsato et al., 2007; Jamieson et al., 2015; Johnson et al., 2006; Nagra et al., 2017; Orland et al., 2014; Treble et al., 2003; Wang et al., 2019), or C and O isotope ratios (Mattey et al., 2008; Treble et al., 2005) can assist in subjugating the limitations of speleothem U-Th dating, and acquiring precise relative age models. Faraji et al. (2021) reconstructed an age-depth model for Pu17 via integrating, in a multivariate analysis, high resolution $(6 \mu \mathrm{m})$ variations in trace elements analyzed by LA-ICP-MS, with optically visible growth bands and two-dimensional Sr-concentration laminae as identified through synchrotron-radiation-based micro XRF (SR- $\mu \mathrm{XRF}$ ) mapping. By tying the U-Th ages to the lamina chronology, Faraji et al. (2021) reconstructed the initial ${ }^{230} \mathrm{Th} /{ }^{232} \mathrm{Th}$ for each U-Th sample analyzed. This combined approach resulted in an age model with only $4 \%$ uncertainty, considerably improving upon the ca. $50 \%$ uncertainty in the U-Th ages. Nu16, on the other hand, yielded unreliable U/Th dates with age inversions, which could not be useful for age model building. However, a laminae counting chronology was obtained for Nu16 via coupling SR- $\mu$ XRF two-dimensional Sr-concentration laminae with optical imaging of annual growth laminae. SR- $\mu$ XRF microscopy that was used for building laminae counting chronology was performed on polished stalagmite samples at the XFM beamline at the Australian Synchrotron (Paterson et al., 2011) equipped with a Maia 384 detector 

array mounted $10 \mathrm{~mm}$ away from the sample target. The beam spot size was $1.5 \mu \mathrm{m}$, and the monochromatic incident energy was set at $18.5 \mathrm{keV}$. The XFM spectral data were analyzed using the GeoPIXE software suite, quantified by using single element Mn, Fe and Pt foils (Micromatter, Canada) and corrected by using a Ca matrix factor (Borsato et al., 2021; Fisher et al., 2015; Ryan et al., 2010).

However, accurate dating of the topmost parts of the two stalagmites remains disputable. That is because the very recent laminations are not evident, and fabrics and growth patterns are complicated, likely due to the simultaneous dissolution and precipitation of calcium carbonate. Therefore, it is reasonable to examine radiocarbon as a potential dating method to build accurate chronologies for the young modern parts of the Atiuan stalagmites.

\subsection{Radiocarbon analysis}

Aliquots of 8-10 mg of carbonate powders were obtained from the two stalagmites using a MicroMill 2002 Desktop Milling Machine equipped with tungsten carbide dental drills with a drill bit diameter of $1 \mathrm{~mm}$, and micromilling continuously at $300 \mu \mathrm{m}$ along the central growth axis of the stalagmite. Based on the constructed lamina-based chronologies, 18 samples from the top $13 \mathrm{~mm}$ of Pu17 and 24 samples from the top $28 \mathrm{~mm}$ of Nu16 were then selected for AMS (accelerator mass spectrometry)

${ }^{14} \mathrm{C}$ analysis. In order to minimize modern atmospheric $\mathrm{CO}_{2}$ contamination, the sampling was carried out one day before the analysis. Powdered samples were then dissolved in $\sim 2 \mathrm{ml}$ of $85 \% \mathrm{H}_{3} \mathrm{PO}_{4}$. Fast carbonate dissolution and complete conversion to $\mathrm{CO}_{2}$ were ensured by heating the sample vials on a hot block at $90^{\circ} \mathrm{C}$ for 1 hour. The evolved $\mathrm{CO}_{2}$ was then converted to graphite using $\mathrm{H}_{2}$ over Fe catalyst (Hua et al., 2001). AMS measurements were carried out using the VEGA accelerator at ANSTO (Fink et al., 2004) with a typical $1 \sigma$ uncertainty of $0.25-0.3 \%$. Results showing the ${ }^{14} \mathrm{C}$ content of the stalagmite samples were reported as percent modern carbon (pMC; Stuiver and Polach, 1977), after correction for machine background, procedural blank, and isotopic fractionation using measured $\delta^{13} \mathrm{C}$. 


\subsection{Radiocarbon age-depth modelling}

195

196

197

198

199

200

201

202

203

204

205

206

207

208

209

210

211

212

213

We employed the ${ }^{14} \mathrm{C}$ bomb-pulse method to date the modern part of the Atiu's speleothems. Building reliable radiocarbon chronologies for speleothems using this method, which exploits the global anthropogenic increase in atmospheric ${ }^{14} \mathrm{C}$ resulting from nuclear testing in the 1950 s and 1960 s CE,

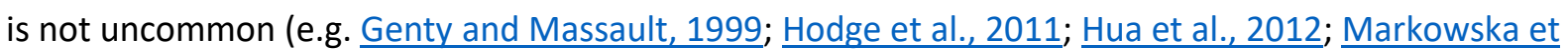
al., 2019; Mattey et al., 2008; Noronha et al., 2015). The rising of the atmospheric ${ }^{14} \mathrm{C}$ concentrations is around 1955 CE (Hua et al., 2013; Hua et al., 2021), reaching its peak in the Northern Hemisphere (NH) in 1963 CE and the Southern Hemisphere (SH) in 1965 CE. The incorporation of the elevated atmospheric ${ }^{14} \mathrm{C}$ into a speleothem provides a means to determine its bomb-pulse profile. This profile was established by using two main anchor points: 1 ) the point where ${ }^{14} \mathrm{C}$ concentrations begin to rise, and 2) the date that the speleothem was retrieved from the cave (for active speleothems). However, ${ }^{14} \mathrm{C}$ transferred from the atmosphere to a speleothem is typically damped and lagged due to the incorporation of $\mathrm{C}$ from the soil organic matter above the cave, which is site-specific and has variable residence times. It is, therefore, crucial to have a thorough understanding of carbon dynamics in the soil zone. Several studies have modelled the age spectrum of soil organic matter to better understand unsaturated zone carbon dynamics (e.g. Carlson et al., 2019; Fohlmeister et al., 2011; Griffiths et al., 2012; Hodge et al., 2011; Noronha et al., 2015). Such models assume that soil gas carbon arises from three different reservoirs with fast, medium and slow turnover times. The ${ }^{14} \mathrm{C}$ content recorded in a speleothem is, thus, dictated by the relative $C$ fraction in those reservoirs. These studies employ a wide variety of prescribed $C$ pool ages ranging between 1 to 10,000 years to simulate the decomposition of organic $\mathrm{C}$ based on the humification model. One potential limitation of these models is averaged or prescribed turnover time of C pools. Markowska et al. (2019) put forward another approach that considers the decay of $\mathrm{C}$ as a continuum. It uses a four-reservoir model and considers ${ }^{14} \mathrm{CO}_{2}$ more broadly in terms of vadose zone (root and microbial respiration) contributions. Markowska et al. (2019)'s approach defines $C$ pools as $C_{1}$ reservoir (turnover $<1$ year), bioavailable $C_{2}$ reservoir (15 years), intermediate, chemically or physically protected $C_{3}$ reservoir (1- 40 years) and a chemically 
or physically protected (nonbioavailable) $\mathrm{C}_{4}$ reservoir (1-1000 years). ${ }^{14} \mathrm{C}$ in this model is represented by an array of Weibull distributions, assuming different contributions from each reservoir. The most appropriate distribution is then determined using a solver function (Markowska et al., 2019), based on the best fit to the speleothem ${ }^{14} \mathrm{C}$ bomb-pulse profile, after accounting for a dead carbon proportion (DCP). The DCP, which is used to account for the contribution of old carbon (from soil and/or limestone bedrock), was calculated as $D C P=\left[1-\left(\frac{14 C_{\text {meas. }}}{14 C_{\text {atm. }}}\right)\right] \times 100 \%$ ( $\underline{\text { from Genty and }}$ content of the coeval atmosphere. We followed this approach to model the soil continuum for Atiu caves and build robust radiocarbon chronologies for Pu17 and Nu16.

\subsection{Construction of final chronologies}

Final age models for Pu17 and Nu16 were constructed by splicing the radiocarbon and laminae age models. We used the Bacon software (Blaauw and Christen, 2011), which applies a stepwise autoregressive Gamma process to generate the final chronologies. By using Bacon, the final chronology for the entire Pu17, derived from the radiocarbon age model for the top $13 \mathrm{~mm}$ and the lamina-based chronology for the whole stalagmite $(50 \mathrm{~mm})$, was constructed. The final age model for the top $40 \mathrm{~mm}$ of Nu16 was also achieved, based on the radiocarbon chronology for the top $28 \mathrm{~mm}$ and the laminaecounting age model for the growth interval of $0-40 \mathrm{~mm}$.

\section{4. Results}

The lamina-based chronology of Pu17 was discussed in Faraji et al. (2021) and is shown in Fig. 2. Following the same methodology, we constructed a chronology for Nu16 based on lamina counting (see Fig. 2) in the absence of LA-ICP-MS trace elements and without age constraints because U-Th age uncertainties are substantially large and are not useful. The laminae chronology was built by assuming the annual nature of laminae and assigning the age of retrieval to the topmost lamina, given that Nu16 was active when collected from the cave. The laminae age model reveals that the top $13 \mathrm{~mm}$ of Pu17, 

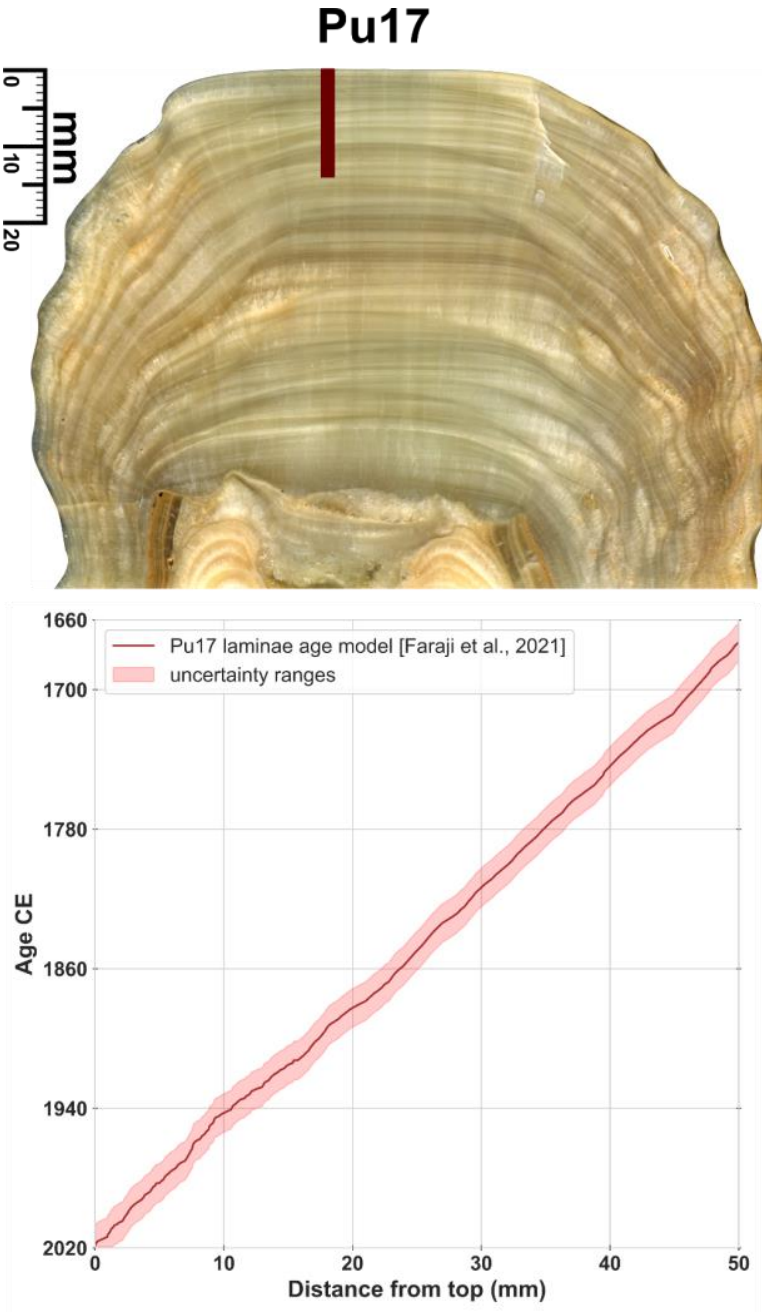
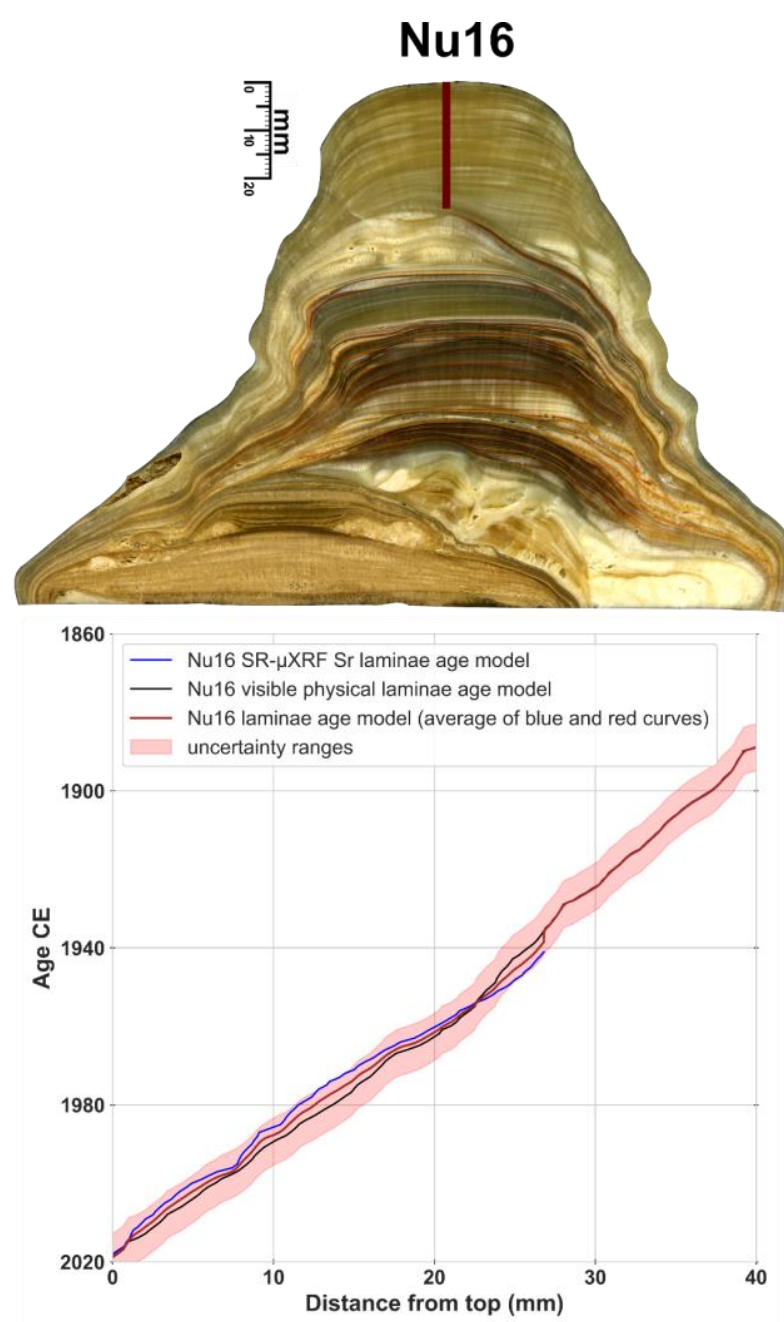

Fig. 2. Stalagmites Pu17 and Nu16, and their laminae counting chronologies. The red bars on the speleothem scans (top panels) show the portions analyzed for ${ }^{14} \mathrm{C}$.

The AMS ${ }^{14} \mathrm{C}$ results are listed in Table 1 and illustrated in Fig. $\mathbf{3}$. The ${ }^{14} \mathrm{C}$ content in Pu17 is $\approx 95 \mathrm{pMC}$ at a depth (distance from the top; DFT) of $12.15 \mathrm{~mm}$, then slightly increases to $\approx 96 \mathrm{pMC}$ at a DFT of $9.45 \mathrm{~mm}$. The $\mathrm{pMC}$ continues rising until it reaches a maximum value of $\approx 130 \mathrm{pMC}$ at $7.95 \mathrm{~mm}$ DFT. The ${ }^{14} \mathrm{C}$ content then fluctuates from $128-129 \mathrm{pMC}$ between7.65 and $7.05 \mathrm{~mm}$ DFT, after which it starts decreasing, to a value of $\approx 104 \mathrm{pMC}$ at the top of Pu17. For Nu16, its ${ }^{14} \mathrm{C}$ content is $\approx 95 \mathrm{pMC}$ at 


\section{Pu17}

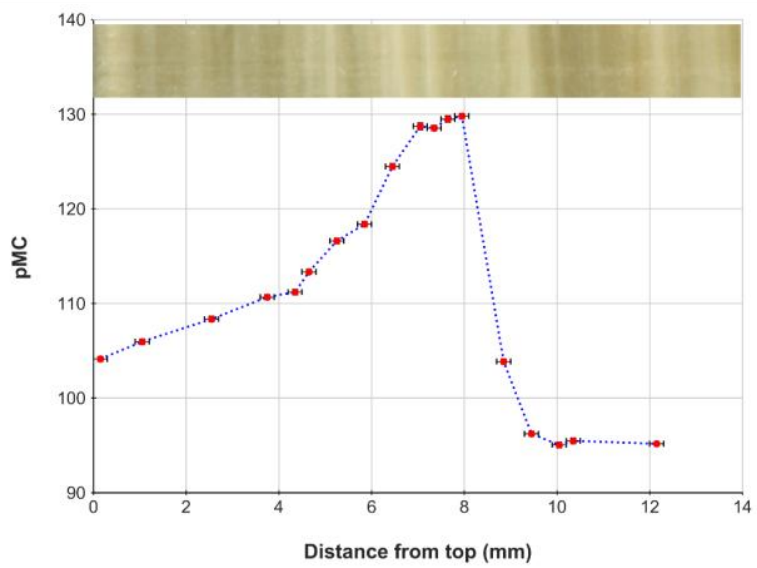

Nu16

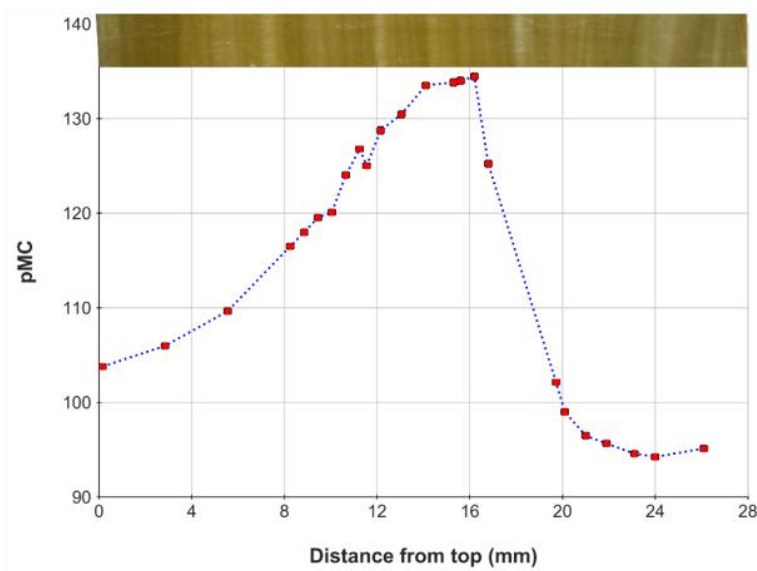

Fig. 3. The ${ }^{14} \mathrm{C}$ content in pMC (percent Modern Carbon) of the samples taken from Pu17 and Nu16 (bottom panels), and the speleothem scans of the portions analyzed for ${ }^{14} \mathrm{C}$ (top panels). 
Table 1. The AMS ${ }^{14} \mathrm{C}$ results for Pu17 and Nu16.

\begin{tabular}{|c|c|c|c|c|}
\hline $\begin{array}{c}\text { Lab ID (ANSTO } \\
\text { Code) }\end{array}$ & Sample ID & $\mathrm{DFT}(\mathrm{mm})$ & ${ }^{14} \mathrm{C} \pm 1 \sigma(p M C)$ & $\delta^{13} \mathrm{C}$ (\%。 VPDB) \\
\hline \multicolumn{5}{|c|}{ Pu17 } \\
\hline OZZ139 & Pu17- 1 & 0.15 & $104.14 \pm 0.26$ & -11.8 \\
\hline OZZ140 & Pu17- 2 & 1.05 & $105.96 \pm 0.28$ & -11.7 \\
\hline OZZ141 & Pu17- 3 & 2.55 & $108.34 \pm 0.30$ & -12.7 \\
\hline OZZ142 & Pu17- 4 & 3.75 & $110.66 \pm 0.26$ & -11.8 \\
\hline OZZ143 & Pu17- 5 & 4.35 & $111.19 \pm 0.27$ & -14.8 \\
\hline OZZ144 & Pu17- 6 & 4.65 & $113.34 \pm 0.28$ & -14.4 \\
\hline OZZ145 & Pu17- 7 & 5.25 & $116.59 \pm 0.28$ & -13.3 \\
\hline OZZ146 & Pu17- 8 & 5.85 & $118.36 \pm 0.28$ & -14.2 \\
\hline OZZ147 & Pu17- 9 & 6.45 & $124.42 \pm 0.30$ & -12.6 \\
\hline OZZ148 & Pu17- 10 & 7.05 & $128.72 \pm 0.34$ & -12.9 \\
\hline OZZ149 & Pu17- 11 & 7.35 & $128.52 \pm 0.28$ & -13.5 \\
\hline OZZ150 & Pu17- 12 & 7.65 & $129.47 \pm 0.32$ & -13.2 \\
\hline OZZ151 & Pu17- 13 & 7.95 & $129.79 \pm 0.28$ & -13.5 \\
\hline OZZ152 & Pu17- 14 & 8.85 & $103.85 \pm 0.26$ & -12.2 \\
\hline OZZ155 & Pu17- 15 & 9.45 & $96.23 \pm 0.25$ & -11.6 \\
\hline OZZ156 & Pu17- 16 & 10.05 & $94.99 \pm 0.27$ & -11.6 \\
\hline OZZ153 & Pu17- 17 & 10.35 & $95.46 \pm 0.29$ & -11.8 \\
\hline OZZ154 & Pu17- 18 & 12.15 & $95.08 \pm 0.23$ & -12.3 \\
\hline \multicolumn{5}{|c|}{ Nu16 } \\
\hline OZZ157 & Nu16-1 & 0.15 & $103.78 \pm 0.28$ & -12.8 \\
\hline OZZ158 & Nu16-2 & 2.85 & $105.96 \pm 0.31$ & -9.0 \\
\hline OZZ159 & Nu16-3 & 5.55 & $109.63 \pm 0.32$ & -8.7 \\
\hline OZZ160 & Nu16-4 & 8.25 & $116.48 \pm 0.30$ & -8.1 \\
\hline OZZ161 & Nu16-5 & 8.85 & $117.96 \pm 0.31$ & -11.1 \\
\hline OZZ162 & Nu16-6 & 9.45 & $119.53 \pm 0.31$ & -11.1 \\
\hline OZZ163 & Nu16-7 & 10.05 & $120.10 \pm 0.31$ & -9.1 \\
\hline OZZ164 & Nu16-8 & 10.65 & $124.01 \pm 0.31$ & -11.0 \\
\hline OZZ165 & Nu16-9 & 11.25 & $126.77 \pm 0.26$ & -12.4 \\
\hline OZZ166 & Nu16-10 & 11.55 & $125.00 \pm 0.26$ & -8.6 \\
\hline OZZ167 & Nu16-11 & 12.15 & $128.73 \pm 0.37$ & -10.0 \\
\hline OZZ168 & Nu16-12 & 13.05 & $130.43 \pm 0.35$ & -8.6 \\
\hline OZZ844 & Nu16-13 & 14.10 & $133.49 \pm 0.31$ & -9.1 \\
\hline OZZ845 & Nu16-14 & 15.30 & $133.80 \pm 0.37$ & -11.1 \\
\hline OZZ849 & Nu16-15 & 15.60 & $133.99 \pm 0.36$ & -10.9 \\
\hline OZZ846 & Nu16-16 & 16.20 & $134.44 \pm 0.36$ & -11.0 \\
\hline OZZ847 & Nu16-17 & 16.80 & $125.20 \pm 0.35$ & -9.5 \\
\hline OZZ848 & Nu16-18 & 19.72 & $102.12 \pm 0.28$ & -10.1 \\
\hline OZY391 & Nu16-19 & 20.10 & $99.00 \pm 0.32$ & -9.8 \\
\hline OZY392 & Nu16-20 & 21.00 & $96.47 \pm 0.32$ & -9.1 \\
\hline OZY393 & Nu16-21 & 21.90 & $95.64 \pm 0.31$ & -9.3 \\
\hline OZY394 & Nu16-22 & 23.10 & $94.54 \pm 0.31$ & -9.3 \\
\hline OZY395 & Nu16-23 & 24.00 & $94.23 \pm 0.30$ & -10.1 \\
\hline OZY396 & Nu16-24 & 26.10 & $95.12 \pm 0.30$ & -9.1 \\
\hline
\end{tabular}


Chronological anchor points must first be assigned to build an age-depth model for Pu17 using the bomb pulse soil continuum method method (Markowska et al., 2019). The first anchor point is based on the 'inflection point' (IP), calculated as the mean $\mathrm{pMC}$ of two radiocarbon samples, the ${ }^{14} \mathrm{C}$ sample where ${ }^{14} \mathrm{C}$ first appears to rise off the baseline and the closest baseline measurement. There were two possibilities for the choice of the IP, either from samples Pu17-14 and -15 (DFT $9.15 \mathrm{~mm}$ ) or from Pu1716 and -17 (DFT $9.75 \mathrm{~mm}$ ), where we observed pMC values rising above the baseline values and hence the onset of bomb radiocarbon being incorporated in the speleothem. The second anchor point used was the extraction date as Pu17 was active when retrieved (Faraji et al., 2021). The age of 2019 CE was assigned to the top of the stalagmite. The date of retrieval and the IP were used as anchor points for the age-depth modelling. The correlation $\left(\mathrm{r}^{2}\right)$ between the modelled data and the measured data (actual) was highest for the age model IP $=9.15 \mathrm{~mm}$, using $1956 \mathrm{CE}$ as the IP year $\left(r^{2}=0.99\right)$ (Fig. 4). This suggests a rapid transfer of the atmospheric ${ }^{14} \mathrm{C}$ to the stalagmite calcite in less than one year, given the onset of atmospheric bomb radiocarbon in the SH was in early 1956 (Hua et al., 2013). The age model indicates the bomb peak recorded in sample Pu-17-13 had an age of 1966 CE, also suggesting negligible time delay in the transfer of atmospheric ${ }^{14} \mathrm{C}$ signal to the stalagmite as atmospheric ${ }^{14} \mathrm{C}$ bomb peak in the SH occurred in 1965 CE (Fig. 5). Moreover, the carbon modelling indicates that $20 \%$ of the $\mathrm{C}$ reservoir comes from an instantaneous source, labelled $\mathrm{C}_{1}$ in Table $\mathbf{2}$. It is, therefore, reasonable to infer an exceptionally fast transfer of atmospheric ${ }^{14} \mathrm{C}$ to Pu17. The age-depth model obtained through the radiocarbon yields a growth rate of $144 \pm 8 \mu \mathrm{m} / \mathrm{year}$ for the top of $13 \mathrm{~mm}$ of Pu17.

For Nu16, the IP was determined to be between samples Nu16-20 and 21 (DFT $21.45 \mathrm{~mm}$ ). The $\mathrm{r}^{2}$ value between the modelled and actual data was 0.97, using 1957 CE as the IP year (onset of the bomb pulse) (Fig. 4). This suggests that there is a slower transfer of the atmospheric carbon signal to Nu16 than that for Pu17. Stalagmite Nu16 was retrieved from the cave in 2018 and was still active. Thus, the age of the stalagmite tip (2018 CE) and the IP were anchor points for age modelling. The Nu16 bomb pulse peak occurs in 1972 CE, within the sample Nu16-16 (Fig. 5). The modelling suggests 
contributions predominately from $C_{2}$ and $C_{3}$, with no contribution from $C_{1}$ or $C_{4}$ (Table 2). Having no contribution from a $\mathrm{C}_{1}$ reservoir also supports that Nu16 may have a slower transfer of atmospheric carbon to the stalagmite than Pu17, and consequently a later bomb peak. The less negative $\delta^{13} \mathrm{C}$ values, presented in Table 1, in Nu16 (mean $=-10.1 \pm 1.3 \%$ VPDB, $n=18$ ) compared to Pu17 (mean $=$ $-12.8 \pm 0.9 \%$ VPDB, $n=24$ ) could be indicative of longer water-host rock interaction times and a slower transmissivity of rain signal to Nu16 compared to Pu17 (Table 1). The average DCP value for Nu16 of

$2.7 \%$ is similar to the DCP value for Pu17 (Table 2). The age-depth model yields a growth rate of $347 \pm$ $10 \mu \mathrm{m} /$ year for the top $28 \mathrm{~mm}$ of Nu16, which is much higher than that of Pu17.

As listed in Table 2, Pu17 has a $21 \%$ contribution from a very fast turnover $C$ reservoir $\left(C_{1}\right)$ which is consistent with the measured data showing a sharp ${ }^{14} \mathrm{C}$ rise from the baseline and an early stalagmite bomb peak. On the other hand, Nu16 has no contribution from the instantaneous $\mathrm{C}$ pool, which results in a longer lag between the timing of the atmospheric bomb peak and that recorded in the stalagmite. Very low DCP values for both Pu17 and Nu16 account for the relatively high bomb peak values (ca. 130 and 134 pMC for Pu17 and Nu16, respectively) (see Fig. 5), which allows reconstructing accurate radiocarbon chronologies for these two stalagmites.
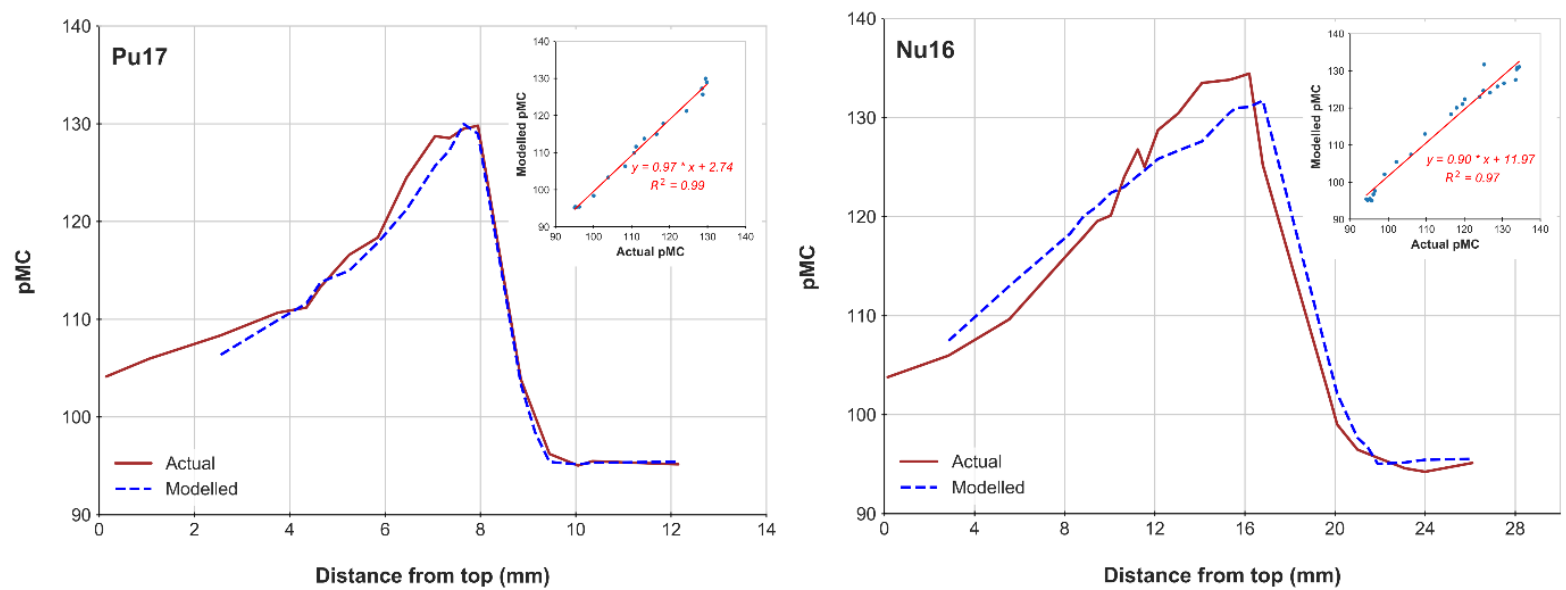
between actual and modelled data is 0.99 for Pu17 and 0.97 for Nu16 (see insert diagrams). 

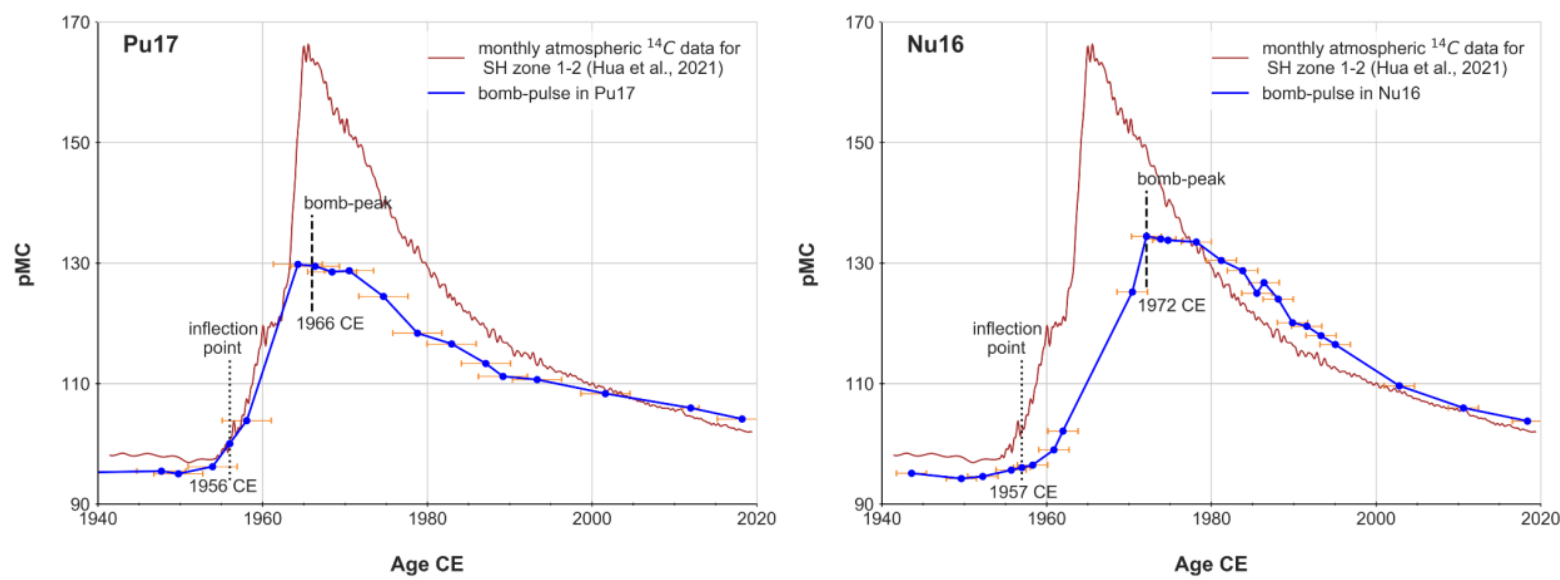

Fig. 5. Bomb pulse modelling for Pu17 and Nu16. Brown curves show monthly atmospheric ${ }^{14} \mathrm{C}$ data for the Southern Hemisphere Zone 1-2 (Hua et al., 2021), and blue curves show the modelled ages for these stalagmites. The onset (inflection point) and the peak of the bomb pulse recorded in the stalagmites are shown. Pu17 shows a sharp and early bomb peak in 1966 CE, whereas Nu16 depicts a later bomb peak in 1972 CE, indicating a slower transfer of atmospheric radiocarbon to the stalagmite.

Table 2. Model output from C modelling shows the contributions (\%) from each C reservoir and average DCP values.

\begin{tabular}{cccccc}
\hline \multirow{2}{*}{ Speleothem } & \multicolumn{4}{c}{ Modelled contribution (\%) from each C reservoir } & Average DCP (\%) \\
\cline { 2 - 5 } & $F\left(C_{1}\right)$ & $F\left(C_{2}\right)$ & $F\left(C_{3}\right)$ & $F\left(C_{4}\right)$ & \pm 1 SD \\
\hline Pu17 & 21 & 33 & 13 & 32 & $2.11 \pm 0.47$ \\
\hline Nu16 & 0 & 57 & 43 & 0 & $2.71 \pm 0.55$ \\
\hline
\end{tabular}

\section{Discussion}

\subsection{Comparison between the bomb curves reported in this study and those in the literature}

322 Comparing the radiocarbon age models of Pu17 and Nu16 with other published radiocarbon chronologies for stalagmites in the SH and the South Pacific show that Pu17 has the earliest bomb peak. In addition, both Pu17 and Nu16 record sharp rises in ${ }^{14} \mathrm{C}$ after the bomb onsets with clearly defined bomb peaks (Fig. 6). Nu16 shows the highest peak pMC value (134.4) recorded in modern SH speleothems, being slightly higher than that in stalagmite WM4 (134.1) from the Wombeyan Caves

327 (Hodge et al., 2011). This is likely due to the minimal overburden (2-8 $\mathrm{m})$ and the sparse soil cover in 
328 Atiu that in some areas, only tree litter is present. The most similar bomb-pulse radiocarbon curve to 329 Pu17 and Nu16 was reported from semi-arid Wellington Caves in southeast Australia (stalagmite WB; 330 Markowska et al. (2019)), where the overburden is $25 \mathrm{~m}$ but has limited soil cover and exposed 331 bedrock (less than $0.3 \mathrm{~m}$ ). Bomb-pulse curves recorded in speleothems from Liang Luar cave in 332 Indonesia (Griffiths et al., 2012), Cold Air cave in South Africa (Sundqvist et al., 2013) and Careys Cave 333 in Australia (Scroxton et al., 2021) are very different from those from Atiu with much-damped bomb $334{ }^{14} \mathrm{C}$ rising and much lower bomb peak values (Fig. 6). That is likely related to the site-specific soil and 335 host rock; since Liang Luar cave is buried under a thick rock burden (30-50 m) and soil cover (1-2 m), 336 the bomb peak recorded in stalagmite B1 of this cave is not clear as that reported for stalagmite T7 of 337 the Cold Air cave with a $20 \mathrm{~m}$ thick overburden and less than $0.3 \mathrm{~m}$ soil. Similarly, Careys Cave has an 338 overburden of $30 \mathrm{~m}$ and a very damped bomb ${ }^{14} \mathrm{C}$. Therefore, the sharp and clear ${ }^{14} \mathrm{C}$ in the Atiuan stalagmites provide excellent age models, paving the way to construct annual records of hydroclimate. 


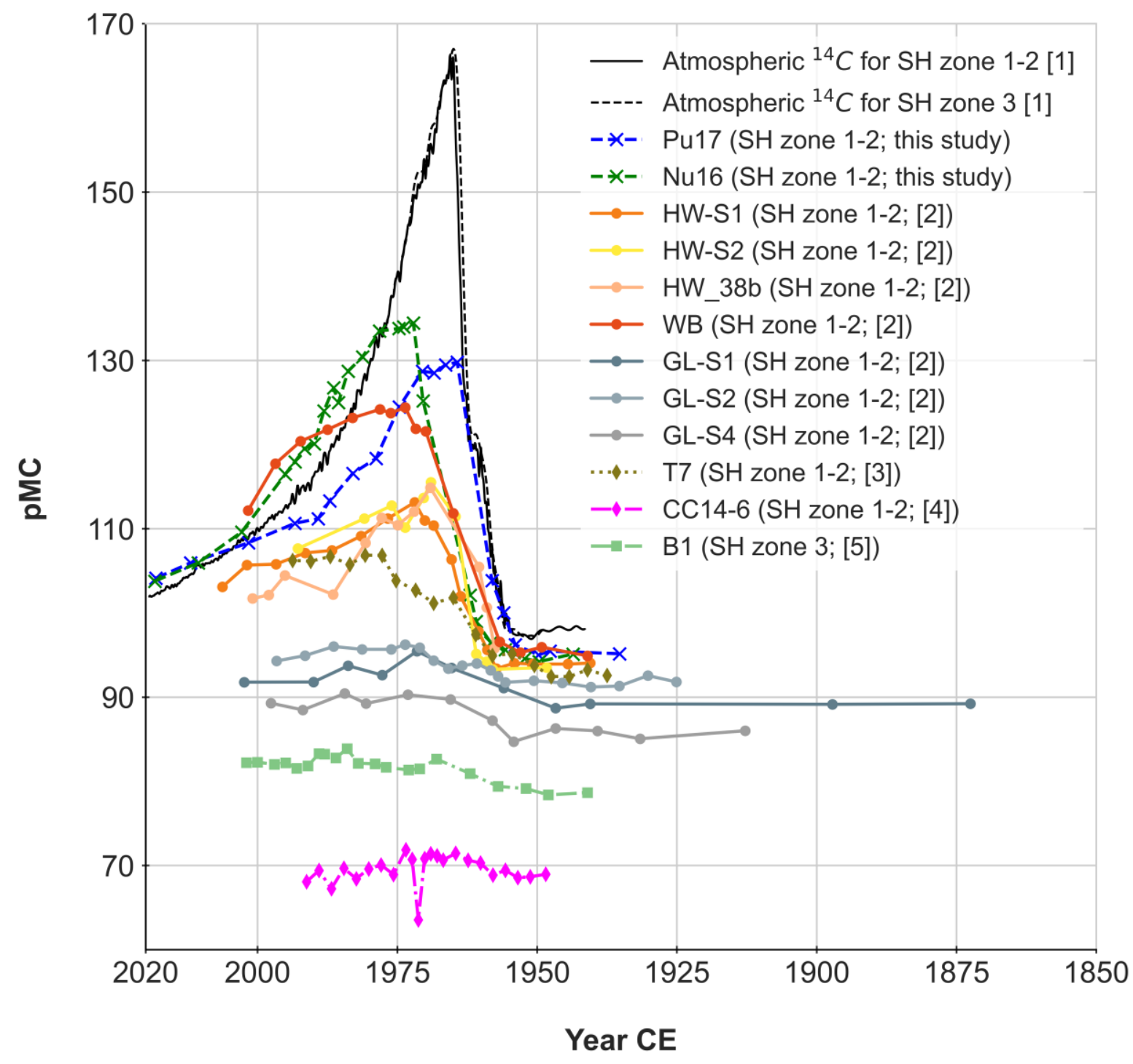

Fig. 6. Some of the published bomb radiocarbon chronologies for speleothems in the SH compared with those recorded in Pu17 and Nu16, and SH atmospheric ${ }^{14} \mathrm{C}$ data. [1] - Hua et al. (2021), [2] - Markowska et al. (2019), [3] - Sundqvist et al. (2013), [4] - Scroxton et al. (2021), and [5] - Griffiths et al. (2012).

\subsection{Radiocarbon vs laminae chronologies, and the final chronologies}

Chronologies based on counting physical and chemical laminae indicate that the top $13 \mathrm{~mm}$ of Pu17 grew for 92 years from 1927 to 2019 CE (Faraji et al., 2021), and the top $28 \mathrm{~mm}$ of Nu16 grew for 76 years from 1942 to 2018 CE. These suggest a mean growth rate of $132 \pm 14 \mu \mathrm{m} /$ year for Pu17 and 313 $\pm 39 \mu \mathrm{m} /$ year for Nu16. The radiocarbon chronologies indicate slightly different growth rates for the 

$\mu \mathrm{m} /$ year).

The age-depth relationship generated by radiocarbon modelling follows a constant annual growth for Pu17 and Nu16, while those obtained by laminae counting show variable annual growth rates. This explains why the laminae counting chronologies and those obtained through radiocarbon modelling are not the same. As shown in Fig. 7, whilst the $1 \sigma$ uncertainty ranges of laminae counting age models encompass those associated with the bomb-pulse models, the difference between the two approaches can be up to nine years for Pu17 and three years for Nu16 within the growth interval. Interestingly, the laminae age models almost always overestimated the age of the stalagmites for at least 2-3 years (Fig. 7). However, for most of the growth interval, the offset between the chronologies
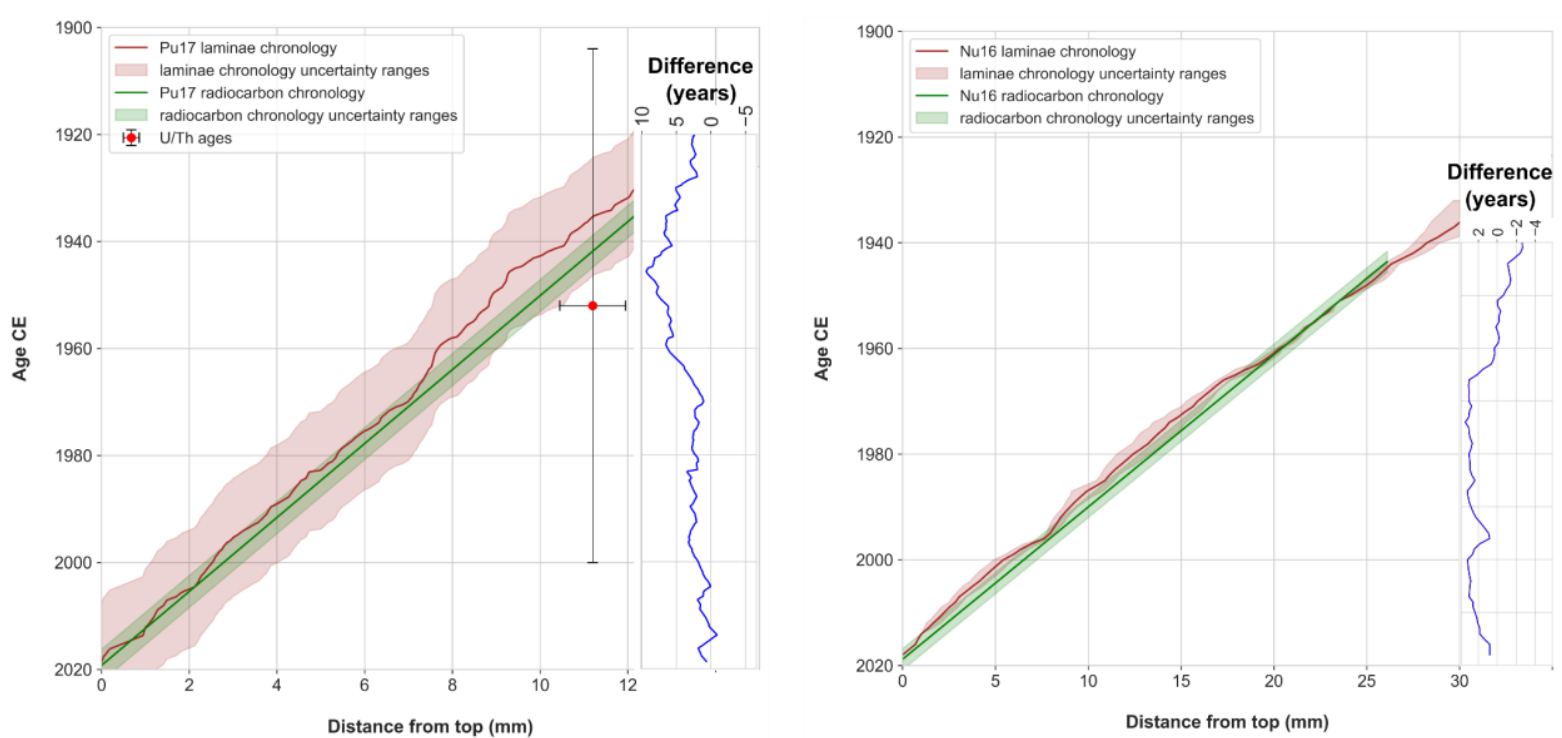

Fig. 7. Comparison of the laminae counting chronology constructed for Pu17 (Faraji et al., 2021) and Nu16 with corresponding radiocarbon chronologies. The offset between the laminae and radiocarbon age models (blue curve) is mostly around 2-3 years, which falls within the age models' $1 \sigma$ uncertainty ranges. $40 \mathrm{~mm}$ of Nu16, the radiocarbon and laminae chronologies were spliced for each stalagmite. For the 
top parts of the stalagmites where the radiocarbon and laminae age models overlap, the final chronologies are closer to the radiocarbon age model than to the laminae counting because radiocarbon has smaller uncertainties than the initial laminae age model both in Pu17 ( \pm 3 vs \pm 11 years) and Nu16 ( \pm 2 vs \pm 6 years). Fig. 8 shows the final chronologies constructed for Pu17 and Nu16. As shown in the figure, the top $13 \mathrm{~mm}$ of Pu17 and top $28 \mathrm{~mm}$ of Nu16, where radiocarbon samples were collected, have narrower ranges of age uncertainties compared to the deeper parts. According to the final chronologies, stalagmite Pu17 grew for 347 years from 1672 to 2019 CE with an average growth
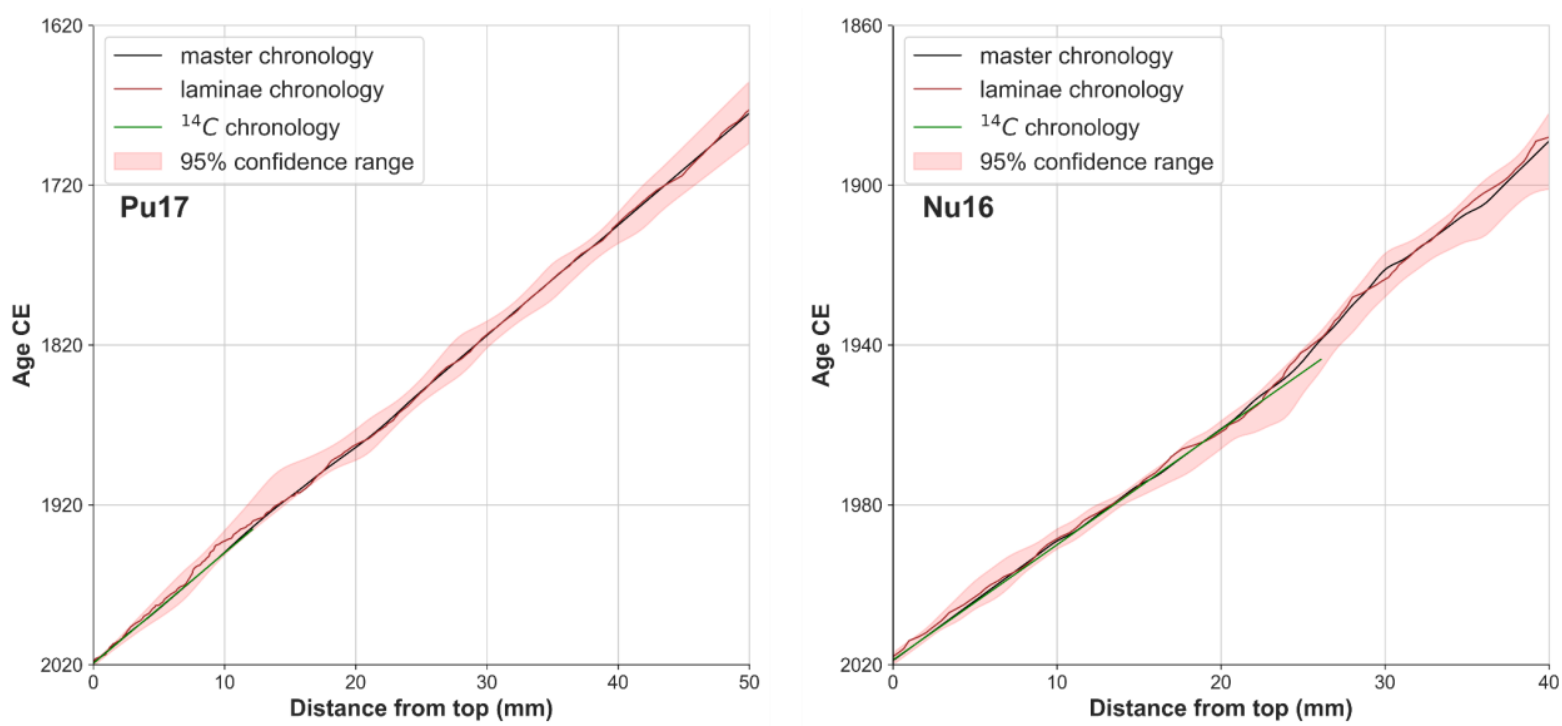

Fig. 8. The final constructed chronologies (black curve) for Pu17 and Nu16 after splicing the radiocarbon (green curve) and laminae age models (brown curve) by using the Bacon age-depth modelling (Blaauw and Christen, 2011). The 95\% confidence ranges were produced by Bacon and are shown in red envelopes. 


\subsection{Implications for regional hydroclimate}

388

In order to demonstrate the significance of the chronologies constructed via combining the radiocarbon dating with laminae counting, we use the Pu17 hydroclimate proxies which were initially discussed in Faraji et al. (2021). By analyzing a group of trace elements including Mg, Na, Sr, Ba through LA-ICP-MS, and then performing a principal component analysis (PCA), Faraji et al. (2021) argued that infiltration - rainfall minus potential evapotranspiration (PET) - is the mechanism controlling the concentration of trace elements in Pu17. They used the Thornthwaite formula (Thornthwaite, 1948) to calculate the PET for Atiu for 1914-2019. The calculated infiltration was then acquired by subtracting the PET from instrumental rainfall data. Faraji et al. (2021) showed that principal component one (PC1) of the PCA, including $\mathrm{Mg}, \mathrm{Na}, \mathrm{Sr}, \mathrm{Ba}$ that accounts for $42 \%$ variance in the trace elements, correlates positively with infiltration (and thus rainfall). As such, the more positive values of PC1 should correspond to higher infiltration, whilst its negative values should coincide with lower infiltration. In Fig. 9, the PC1 is compared with the calculated infiltration in Atiu by using both the laminae chronology (Fig. 9a) and the final chronology constructed in this study (Fig. 9b). In both cases, PC1 follows the variation in infiltration and more positive values of PC1 point to higher infiltration. However, when PC1 was plotted using the final age model developed in this study, it showed a much clear relationship with infiltration with a higher correlation coefficient $(r=0.20)$ than when plotted using the laminae age model $(r=0.13)$. This corroborates the idea that infiltration is the overarching mechanism controlling the variability of trace elements in Pu17, even though each element might originate from a different source Faraji et al. (2021). This also reveals the excellent potential of speleothems from the Cook Islands to provide reliable information, at least, on the historical variability of the El Niño Southern Oscillation (ENSO). That is because the ENSO, represented by Southern Oscillation Index (SOI) in Fig. 9c, drives much of the interannual variation in rainfall (and thus infiltration) in the Pacific Islands (Weir et al., 2021). El Niño events are generally associated with relatively dry periods and less rainfall in the southern Cook Islands, whereas La Niña events mark wet periods (see Fig. 9c). Precisely-dated high-resolution proxies of infiltration - for example, PC1 in Pu17 


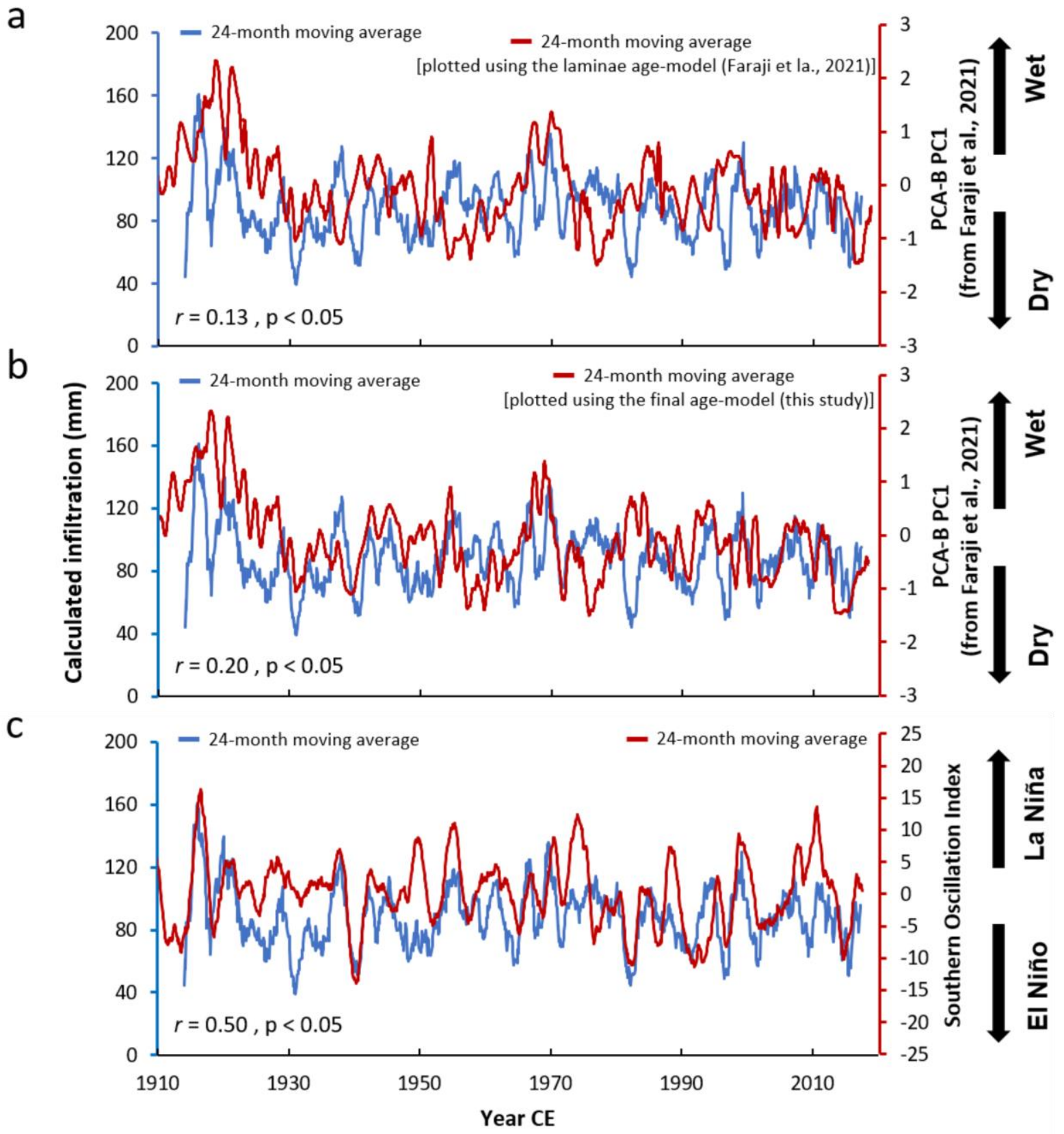

Fig. 9. The laminae age model (a) and the final chronology constructed in this study (b) in comparison with the PC1 - of PCA$B$ in Faraji et al. (2021) - as a hydroclimate proxy with the calculated infiltration. In both cases, PC1 follows the variation in infiltration, and more positive values of PC1 correspond to higher infiltration (wet) and vice versa. However, when PC1 was plotted using the age model developed in this study, it showed a far more clear relationship with infiltration (b) than when plotted using the laminae age model (a). The calculated infiltration is also plotted against the Southern Oscillation Index (representing ENSO), showing a strong link between dry (wet) periods and EI Niño (La Niña) events. The instrumental record for SOI was acquired from the Australian Bureau of Meteorology website at: http://www.bom.gov.au/. 
Therefore, it is clear that joint use of bomb radiocarbon and laminae counting chronologies has improved the fit between the calculated infiltration and the PC1 data, paving the way towards obtaining well-dated climate records from Atiuan stalagmites. The combined chronology has improved the accuracy and precision of the age model in the very young parts of the stalagmites, which are otherwise hard to date due to significant uncertainties of $U / T h$ dating and also complexities in the fabrics and possible occurrence of sub-annual laminae. Faraji et al. (2021) were able to decrease the uncertainty of $\mathrm{U} / \mathrm{Th}$ chronology by $45 \%$ via counting visible physical and chemical laminae. However, that laminae age model still had some $4 \%$ uncertainty. The final constructed chronology developed in this study further constrained the age model for Pu17 by reducing the uncertainty for the top $13 \mathrm{~mm}$ of the stalagmite by $3 \%$. The final chronology for Nu16 has only $2 \%$ uncertainty in the top $28 \mathrm{~mm}$ and up to $4 \%$ at DFT $40 \mathrm{~mm}$.

Therefore, even though speleothems from the tropical South Pacific commonly suffer from large uncertainties in their U-Th dating, the use of our combined chronological approach allows us to reduce dating uncertainty and examine paleoclimate records at annual resolution. That is because these speleothems usually benefit from a rapid transmissivity of rainfall in shallow caves with a porous or fractured host rock. Additionally, little soil cover or tree litter further facilitates transmissivity. This, in an environment with seasonal contrast in precipitation (or in cave ventilation/breathing), could potentially lead to the development of both physical and chemical annual laminae in speleothems. Using the combined approach of ${ }^{14} \mathrm{C}$ modelling and visible and chemical laminae counting for tropical Pacific examples can improve the accuracy of dating tremendously, as was shown in this study. This opens up the possibility of obtaining annually resolved hydroclimate records that advances knowledge about pre-instrumental hydroclimate variability in the tropical South Pacific and reduces uncertainties about the magnitude, frequency and duration of past droughts and pluvials. 


\section{Conclusion}

450 Two stalagmites from Southern Cook Islands in the tropical South Pacific were dated using the ${ }^{14} \mathrm{C}$ 451 bomb pulse soil continuum method from Markowska et al. (2019). Results indicate that the onset of 452 the bomb-pulse in Pu17 starts in 1956 and reaches its bomb peak in 1966 CE. The carbon modelling also indicates a $20 \%$ contribution from $C_{1}$ - an instantaneous $C$ source. These data suggest an exceptionally fast transfer of atmospheric carbon to the stalagmite $<1$ year, which was also supported by very negative $\delta^{13} \mathrm{C}$ values in Pu17 (<-12 \% VPDB). The age-depth modelling for Nu16 was indicative of a slower transfer of atmospheric carbon to the stalagmite than Pu17, with a bomb radiocarbon onset and bomb peak in 1957 and $1972 \mathrm{CE}$, respectively. This was corroborated by less negative $\delta^{13} \mathrm{C}$ values in Nu16 (-8 to $-11 \%$ ) than Pu17 (-11 to $-15 \%$ ), and also by the carbon modelling that points out no contribution from $C_{1}$ reservoirs.

The low DCP values (2-3\%) in both Pu17 and Nu16, leading to their high bomb peak of 130-134 pMC, render such accurate radiocarbon chronologies possible. According to the radiocarbon chronologies constructed in this study, the top $13 \mathrm{~mm}$ of Pu17 grew for 89 years (1930 - 2019 CE) with a constant growth rate of $144 \mu \mathrm{m} /$ year. The top $28 \mathrm{~mm}$ of Nu16 grew for 78 years (1940 - $2018 \mathrm{CE}$ ) with a rate more than double that of Pu17, around $347 \mu \mathrm{m} /$ year. The radiocarbon chronologies and available laminae counting age models were then spliced to achieve a single master chronology for each stalagmite. The final age models suggest that Pu17 grew for 347 years from 1672 to 2019 CE, and the top $40 \mathrm{~mm}$ of the stalagmite Nu16 grew for 130 years from 1888 to 2018 CE.

Based on the final constructed chronology, we compared the already published Pu17 proxies of hydroclimate with the calculated infiltration record in Atiu, which showed great agreement between the two series. This supports the accuracy of the final age-depth model. This also attests to the great potential of Pu17, and likely Nu16 as well, to advance knowledge about pre-instrumental hydroclimate variability in the tropical South Pacific. This study is an example of ${ }^{14} \mathrm{C}$ age modelling combined with 
474 otherwise hard-to-date tropical Pacific speleothems. Such accurate and precise chronologies allow

475 obtaining robust paleoclimate records for the climate-vulnerable South Pacific Island communities

476 through enhancing the quality of the calibration of climate proxy data with the current and

477 instrumental weather parameters measured at both cave surface and interior. 


\section{Declaration of competing interest statement}

479 The authors declare that they have no known competing financial interests or personal relationships

480 that could have appeared to influence the work reported in this paper.

481

482 Acknowledgements

483 Special thanks to the landowners, people and Island Council, and to the National Research Committee

484 of the Cook Islands for permission to explore the caves of Atiu and take samples, and to Tura Koronui

485 and George Mateariki, who introduced us to the caves in Atiu. The radiocarbon analysis was carried

486 out at ANSTO. This study was supported by the Australian Research Council Discovery Project grant

487 DP160101058. M.F. was supported by the Australian Government through an "Australian Government

488 Research Training Program Scholarship" and was also supported by The Australian Institute of Nuclear

489 Science and Engineering through a Postgraduate Research Award (award ALNSTU12486).

490

491

492 
Bajo, P., Borsato, A., Drysdale, R., Hua, Q., Frisia, S., Zanchetta, G., Hellstrom, J., and Woodhead, J., 2017, Stalagmite carbon isotopes and dead carbon proportion (DCP) in a near-closed-system situation: An interplay between sulphuric and carbonic acid dissolution: Geochimica et Cosmochimica Acta, v. 210, p. 208-227. https://doi.org/10.1016/j.gca.2017.04.038

Baker, A., C. Hellstrom, J., Kelly, B. F. J., Mariethoz, G., and Trouet, V., 2015, A composite annualresolution stalagmite record of North Atlantic climate over the last three millennia: Scientific Reports, v. 5, p. 10307. https://doi.org/10.1038/srep10307

Baker, A., Mariethoz, G., Comas-Bru, L., Hartmann, A., Frisia, S., Borsato, A., Treble, P. C., and Asrat, A., 2021, The Properties of Annually Laminated Stalagmites-A Global Synthesis: Reviews of Geophysics, v. 59, no. 2, p. e2020RG000722. https://doi.org/10.1029/2020RG000722

Ban, F., Baker, A., Marjo, C. E., Duan, W., Li, X., Han, J., Coleborn, K., Akter, R., Tan, M., and Nagra, G., 2018, An optimized chronology for a stalagmite using seasonal trace element cycles from Shihua Cave, Beijing, North China: Scientific Reports, v. 8, no. 1, p. 4551. https://doi.org/10.1038/s41598-018-22839-z

Bar-Matthews, M., Ayalon, A., Kaufman, A., and Wasserburg, G. J., 1999, The Eastern Mediterranean paleoclimate as a reflection of regional events: Soreq cave, Israel: Earth and Planetary Science Letters, v. 166, no. 1, p. 85-95. https://doi.org/10.1016/S0012-821X(98)00275-1

Barnett, J., 2011, Dangerous climate change in the Pacific Islands: food production and food security: Regional Environmental Change, v. 11, no. 1, p. 229-237. https://doi.org/10.1007/s10113010-0160-2

Beck, J. W., Richards, D. A., Lawrence, R., Edwards, Silverman, B. W., Smart, P. L., Donahue, D. J., Hererra-Osterheld, S., Burr, G. S., Calsoyas, L., Timothy , A. J., Jull, and Biddulph, D., 2001, Extremely Large Variations of Atmospheric $14 \mathrm{C}$ Concentration During the Last Glacial Period: Science, v. 292, no. 5526, p. 2453-2458. https://doi.org/10.1126/science.1056649

Blaauw, M., and Christen, J. A., 2011, Flexible paleoclimate age-depth models using an autoregressive gamma process: Bayesian Analysis, v. 6, no. 3, p. 457-474, 418. https://doi.org/10.1214/11BA618

Borsato, A., Frisia, S., Fairchild, I. J., Somogyi, A., and Susini, J., 2007, Trace element distribution in annual stalagmite laminae mapped by micrometer-resolution $X$-ray fluorescence: implications for incorporation of environmentally significant species: Geochimica et Cosmochimica Acta, v. 71, no. 6, p. 1494-1512. https://doi.org/10.1016/j.gca.2006.12.016

Borsato, A., Frisia, S., Howard, D., and Greig, A., 2021, A guide to synchrotron hard X-ray fluorescence mapping of annually laminated stalagmites: Sample preparation, analysis and evaluation: Spectrochimica Acta Part B: Atomic Spectroscopy, p. 106308. https://doi.org/10.1016/j.sab.2021.106308

Bruce, J. G., 1983, Patterns and classification by soil taxonomy of the soils of the southern cook islands: Geoderma, v. 31, no. 4, p. 301-323. https://doi.org/10.1016/0016-7061(83)90043-5

Cai, W., Santoso, A., Wang, G., Yeh, S.-W., An, S.-I., Cobb, K. M., Collins, M., Guilyardi, E., Jin, F.-F., Kug, J.-S., Lengaigne, M., McPhaden, M. J., Takahashi, K., Timmermann, A., Vecchi, G., Watanabe, M., and Wu, L., 2015, ENSO and greenhouse warming: Nature Climate Change, v. 5, no. 9, p. 849-859. https://doi.org/10.1038/nclimate2743

Carlson, P. E., Banner, J. L., Johnson, K. R., Casteel, R. C., and Breecker, D. O., 2019, Carbon cycling of subsurface organic matter recorded in speleothem $14 \mathrm{C}$ records: Maximizing bomb-peak model fidelity: Geochimica et Cosmochimica Acta, v. 246, p. 436-449. https://doi.org/10.1016/j.gca.2018.11.035

Dorale, J. A., Edwards, R. L., Alexander, E. C., Shen, C.-C., Richards, D. A., and Cheng, H., Uranium-Series Dating of Speleothems: Current Techniques, Limits, \& Applications, Boston, MA, 2004, Springer US, p. 177-197. 
Fairchild, I. J., and Baker, A., 2012, Speleothem science: from process to past environments, John Wiley \& Sons.

Faraji, M., Borsato, A., Frisia, S., Hellstrom, J. C., Lorrey, A., Hartland, A., Greig, A., and Mattey, D. P., 2021, Accurate dating of stalagmites from low seasonal contrast tropical Pacific climate using Sr 2D maps, fabrics and annual hydrological cycles: Scientific Reports, v. 11, no. 1, p. 2178. https://doi.org/10.1038/s41598-021-81941-x

Fink, D., Hotchkis, M., Hua, Q., Jacobsen, G., Smith, A. M., Zoppi, U., Child, D., Mifsud, C., van der Gaast, H., Williams, A., and Williams, M., 2004, The ANTARES AMS facility at ANSTO: Nuclear Instruments and Methods in Physics Research Section B: Beam Interactions with Materials and Atoms, v. 223-224, p. 109-115. https://doi.org/10.1016/j.nimb.2004.04.025

Fisher, L. A., Fougerouse, D., Cleverley, J. S., Ryan, C. G., Micklethwaite, S., Halfpenny, A., Hough, R. M., Gee, M., Paterson, D., Howard, D. L., and Spiers, K., 2015, Quantified, multi-scale X-ray fluorescence element mapping using the Maia detector array: application to mineral deposit studies: Mineralium Deposita, v. 50, no. 6, p. 665-674. https://doi.org/10.1007/s00126-0140562-z

Fohlmeister, J., Kromer, B., and Mangini, A., 2011, The Influence of Soil Organic Matter Age Spectrum on the Reconstruction of Atmospheric 14C Levels via Stalagmites, v. 53, no. 1, p. 99 - 115. https://doi.org/10.1017/s003382220003438x

Genty, D., and Massault, M., 1999, Carbon transfer dynamics from bomb-14C and $\delta 13 C$ time series of a laminated stalagmite from SW France-modelling and comparison with other stalagmite records: Geochimica et Cosmochimica Acta, v. 63, no. 10, p. 1537-1548. https://doi.org/10.1016/S0016-7037(99)00122-2

Goslar, T., Hercman, H., and Pazdur, A., 2000, Comparison of U-Series and Radiocarbon Dates of Speleothems, v. 42, no. 3, p. 403 - 414. https://doi.org/10.1017/s0033822200030332

Griffiths, M. L., Fohlmeister, J., Drysdale, R. N., Hua, Q., Johnson, K. R., Hellstrom, J. C., Gagan, M. K., and Zhao, J. X., 2012, Hydrological control of the dead carbon fraction in a Holocene tropical speleothem: Quaternary Geochronology, v. 14, p. 81-93. https://doi.org/10.1016/j.quageo.2012.04.001

Harmon, R. S., Ford, D. C., and Schwarcz, H. P., 1977, Interglacial chronology of the Rocky and Mackenzie Mountains based upon 230Th-234U dating of calcite speleothems: Canadian Journal of Earth Sciences, v. 14, no. 11, p. 2543-2552. https://doi.org/10.1139/e77-220

Held, I. M., and Soden, B. J., 2006, Robust Responses of the Hydrological Cycle to Global Warming: Journal of Climate, v. 19, no. 21, p. 5686-5699. https://doi.org/10.1175/jcli3990.1

Hellstrom, J., 2003, Rapid and accurate U/Th dating using parallel ion-counting multi-collector ICP-MS: Journal of Analytical Atomic Spectrometry, v. 18, no. 11, p. 1346. https://doi.org/10.1039/b308781f

Hellstrom, J., 2006, U-Th dating of speleothems with high initial 230Th using stratigraphical constraint: Quaternary Geochronology, v. 1, no. 4, p. 289-295. https://doi.org/10.1016/j.quageo.2007.01.004

Hodge, E., McDonald, J., Fischer, M., Redwood, D., Hua, Q., Levchenko, V., Drysdale, R., Waring, C., and Fink, D., 2011, Using the 14C Bomb Pulse to Date Young Speleothems: Radiocarbon, v. 53, no. 2, p. 345-357. https://doi.org/10.1017/\$0033822200056605

Holland, P., and Olson, S., 1989, Introduced versus native plants in austral forests: Progress in Physical Geography: Earth and Environment, v. 13, no. 2, p. 260-293. https://doi.org/10.1177/030913338901300205

Hua, Q., Barbetti, M., and Rakowski, A. Z., 2013, Atmospheric Radiocarbon for the Period 1950-2010: Radiocarbon, v. 55, no. 4, p. 2059-2072. https://doi.org/10.2458/azu_js_rc.v55i2.16177

Hua, Q., Jacobsen, G. E., Zoppi, U., Lawson, E. M., Williams, A. A., Smith, A. M., and McGann, M. J., 2001, Progress in radiocarbon target preparation at the ANTARES AMS Centre: Radiocarbon, v. 43, no. 2A, p. 275-282. https://doi.org/10.1017/S003382220003811X 
Hua, Q., McDonald, J., Redwood, D., Drysdale, R., Lee, S., Fallon, S., and Hellstrom, J., 2012, Robust chronological reconstruction for young speleothems using radiocarbon: Quaternary Geochronology, v. 14, p. 67-80. https://doi.org/10.1016/j.quageo.2012.04.017

Hua, Q., Turnbull, J. C., Santos, G. M., Rakowski, A. Z., Ancapichún, S., De Pol-Holz, R., Hammer, S., Lehman, S. J., Levin, I., Miller, J. B., Palmer, J. G., and Turney, C. S. M., 2021, Atmospheric radiocarbon for the period 1950-2019: Radiocarbon, p. 1-23. https://doi.org/10.1017/RDC.2021.95

Jamieson, R. A., Baldini, J. U. L., Frappier, A. B., and Müller, W., 2015, Volcanic ash fall events identified using principal component analysis of a high-resolution speleothem trace element dataset: Earth and Planetary Science Letters, v. 426, p. 36-45. https://doi.org/10.1016/j.epsl.2015.06.014

Johnson, K., Hu, C., Belshaw, N., and Henderson, G., 2006, Seasonal trace-element and stable-isotope variations in a Chinese speleothem: The potential for high-resolution paleomonsoon reconstruction: Earth and Planetary Science Letters, v. 244, no. 1-2, p. 394-407. https://doi.org/10.1016/j.epsl.2006.01.064

Kirch, P. V., 2000, On the road of the winds: an archaeological history of the Pacific Islands before the European contact, Berkeley, California : University of California Press.

Li, H.-C., Ku, T.-L., You, C.-F., Cheng, H., Edwards, R. L., Ma, Z.-B., Tsai, W.-S., and Li, M.-D., 2005, $87 \mathrm{Sr} / 86 \mathrm{Sr}$ and $\mathrm{Sr} / \mathrm{Ca}$ in speleothems for paleoclimate reconstruction in Central China between 70 and 280 kyr ago: Geochimica et Cosmochimica Acta, v. 69, no. 16, p. 3933-3947. https://doi.org/10.1016/j.gca.2005.01.009

Markowska, M., Fohlmeister, J., Treble, P. C., Baker, A., Andersen, M. S., and Hua, Q., 2019, Modelling the $14 \mathrm{C}$ bomb-pulse in young speleothems using a soil carbon continuum model: Geochimica et Cosmochimica Acta, v. 261, p. 342-367. https://doi.org/10.1016/j.gca.2019.04.029

Marshall, P., 1930, Geology of Rarotonga and Atiu, Bernice P. Bishop Museum Bulletin, v. 72.

Mattey, D., Lowry, D., Duffet, J., Fisher, R., Hodge, E., and Frisia, S., 2008, A 53 year seasonally resolved oxygen and carbon isotope record from a modern Gibraltar speleothem: Reconstructed drip water and relationship to local precipitation: Earth and Planetary Science Letters, v. 269, no. 1-2, p. 80-95. https://doi.org/10.1016/j.epsl.2008.01.051

Meteorology, A. B. o., and CSIRO, 2011, Climate Change in the Pacific: Scientific Assessment and New Research. Volume 2. Country Reports.

Miorandi, R., Borsato, A., Frisia, S., Fairchild, I. J., and Richter, D. K., 2010, Epikarst hydrology and implications for stalagmite capture of climate changes at Grotta di Ernesto (NE Italy): results from long-term monitoring: Hydrological Processes, v. 24, no. 21, p. 3101-3114. https://doi.org/10.1002/hyp.7744

Nagra, G., Treble, P. C., Andersen, M. S., Bajo, P., Hellstrom, J., and Baker, A., 2017, Dating stalagmites in mediterranean climates using annual trace element cycles: Sci Rep, v. 7, no. 1, p. 621. https://doi.org/10.1038/s41598-017-00474-4

Noronha, A. L., Johnson, K. R., Southon, J. R., Hu, C., Ruan, J., and McCabe-Glynn, S., 2015, Radiocarbon evidence for decomposition of aged organic matter in the vadose zone as the main source of speleothem carbon: Quaternary Science Reviews, v. 127, p. 37-47. https://doi.org/10.1016/j.quascirev.2015.05.021

Oriani, F., Treble, P. C., Baker, A., and Mariethoz, G., 2022, WICount: Geological lamination detection and counting using an image analysis approach: Computers \& Geosciences, v. 160, p. 105037. https://doi.org/10.1016/j.cageo.2022.105037

Orland, I. J., Burstyn, Y., Bar-Matthews, M., Kozdon, R., Ayalon, A., Matthews, A., and Valley, J. W., 2014, Seasonal climate signals (1990-2008) in a modern Soreq Cave stalagmite as revealed by high-resolution geochemical analysis: Chemical Geology, v. 363, p. 322-333. https://doi.org/10.1016/j.chemgeo.2013.11.011

Paterson, D., de Jonge, M. D., Howard, D. L., Lewis, W., McKinlay, J., Starritt, A., Kusel, M., Ryan, C. G., Kirkham, R., Moorhead, G., Siddons, D. P., McNulty, I., Eyberger, C., and Lai, B., 2011, The X- 
ray Fluorescence Microscopy Beamline at the Australian Synchrotron, p. 219-222. https://doi.org/10.1063/1.3625343

Richards, D. A., Bottrell, S. H., Cliff, R. A., Ströhle, K., and Rowe, P. J., 1998, U-Pb dating of a speleothem of Quaternary age: Geochimica et Cosmochimica Acta, v. 62, no. 23, p. 3683-3688. https://doi.org/10.1016/S0016-7037(98)00256-7

Ryan, C. G., Kirkham, R., Siddons, D. P., Dunn, P. A., Laird, J. S., Kuczewski, A., Moorhead, G., De Geronimo, G., Davey, P., Jensen, M., Paterson, D. J., de Jonge, M. D., Howard, D. L., and Hough, R. M., 2010, The Maia 384 detector array in a nuclear microprobe: A platform for high definition PIXE elemental imaging: Nuclear Instruments and Methods in Physics Research Section B: Beam Interactions with Materials and Atoms, v. 268, no. 11, p. 1899-1902. https://doi.org/10.1016/j.nimb.2010.02.052

Scholz, D., and Hoffmann, D., 2008, 230Th/U-dating of fossil corals and speleothems: E\&G Quaternary Science Journal, v. 57, no. 1-2. http://doi.org/10.23689/fidgeo-1056

Scroxton, N., Walczak, M., Markowska, M., Zhao, J.-x., and Fallon, S., 2021, Historical droughts in Southeast Australia recorded in a New South Wales stalagmite: The Holocene, v. 31, no. 4, p. 607-617. https://doi.org/10.1177/0959683620981717

Stoddart, D. R., Woodroffe, C., and Spencer, T., 1990, Mauke, Mitiaro and Atiu: Geomorphology of makatea islands in the southern Cooks. https://doi.org/10.5479/si.00775630.341.1

Stuiver, M., and Polach, H. A., 1977, Discussion Reporting of 14C Data: Radiocarbon, v. 19, no. 3, p. 355-363. https://doi.org/10.1017/S0033822200003672

Sundqvist, H. S., Holmgren, K., Fohlmeister, J., Zhang, Q., Matthews, M. B., Spötl, C., and Körnich, H., 2013, Evidence of a large cooling between 1690 and 1740 AD in southern Africa: Scientific Reports, v. 3, no. 1, p. 1767. https://doi.org/10.1038/srep01767

Tan, M., Baker, A., Genty, D., Smith, C., Esper, J., and Cai, B., 2006, Applications of stalagmite laminae to paleoclimate reconstructions: Comparison with dendrochronology/climatology: Quaternary Science Reviews, v. 25, no. 17, p. 2103-2117. https://doi.org/10.1016/j.quascirev.2006.01.034

Treble, P., Shelley, J. M. G., and Chappell, J., 2003, Comparison of high resolution sub-annual records of trace elements in a modern (1911-1992) speleothem with instrumental climate data from southwest Australia: Earth and Planetary Science Letters, v. 216, no. 1-2, p. 141-153. https://doi.org/10.1016/s0012-821x(03)00504-1

Treble, P. C., Chappell, J., Gagan, M. K., McKeegan, K. D., and Harrison, T. M., 2005, In situ measurement of seasonal $\delta 180$ variations and analysis of isotopic trends in a modern speleothem from southwest Australia: Earth and Planetary Science Letters, v. 233, no. 1, p. 17-32. https://doi.org/10.1016/j.epsl.2005.02.013

Trotter, M. M., and Duff, R., 1974, Prehistory of the Southern Cook Islands, Canterbury Museum Trust Board.

Vansteenberge, S., de Winter, N. J., Sinnesael, M., Verheyden, S., Goderis, S., Van Malderen, S. J. M., Vanhaecke, F., and Claeys, P., 2020, Reconstructing seasonality through stable-isotope and trace-element analyses of the Proserpine stalagmite, Han-sur-Lesse cave, Belgium: indications for climate-driven changes during the last 400 years: Clim. Past, v. 16, no. 1, p. 141-160. https://doi.org/10.5194/cp-16-141-2020

Wang, J. K., Johnson, K. R., Borsato, A., Amaya, D. J., Griffiths, M. L., Henderson, G. M., Frisia, S., and Mason, A., 2019, Hydroclimatic variability in Southeast Asia over the past two millennia: Earth and Planetary Science Letters, v. 525, p. 115737. https://doi.org/10.1016/j.epsl.2019.115737

Weir, T., Kumar, R., and Ngari, A., 2021, Interdecadal modulation of the effect of ENSO on rainfall in the southwestern Pacific: Journal of Southern Hemisphere Earth Systems Science, v. 71, no. 1, p. 53-65. https://doi.org/10.1071/ES19053

Widlansky, M. J., Timmermann, A., Stein, K., McGregor, S., Schneider, N., England, M. H., Lengaigne, M., and Cai, W., 2012, Changes in South Pacific rainfall bands in a warming climate: Nature Climate Change, v. 3, p. 417. https://doi.org/10.1038/nclimate1726 
694

695

696

697

698

699

700
Xie, S.-P., Deser, C., Vecchi, G. A., Ma, J., Teng, H., and Wittenberg, A. T., 2010, Global Warming Pattern Formation: Sea Surface Temperature and Rainfall: Journal of Climate, v. 23, no. 4, p. 966-986. https://doi.org/10.1175/2009jcli3329.1

Zhao, J.-x., Wang, Y.-j., Collerson, K. D., and Gagan, M. K., 2003, Speleothem U-series dating of semisynchronous climate oscillations during the last deglaciation: Earth and Planetary Science Letters, v. 216, no. 1, p. 155-161. https://doi.org/10.1016/S0012-821X(03)00501-6 